\title{
Disclosure Quality on Governance Issues in Annual Reports
}

$$
\text { of Malaysian PLCs }
$$

\author{
Rusnah Muhamad (Corresponding author) \\ Faculty of Business and Accounting, University of Malaya \\ 50603 Kuala Lumpur, Malaysia \\ Tel: 60-3-7967-3934 E-mail: rusnahm@gmail.com
}

Suhaily Shahimi

Faculty of Business and Accounting, University of Malaya

50603 Kuala Lumpur, Malaysia

Tel: 60-3-7967-3905Ｅ-mail:suhaily@um.edu.my

Yazkhiruni Yahya

Faculty of Business and Accounting, University of Malaya 50603 Kuala Lumpur, Malaysia

Tel: 60-3-7967-3905 E-mail: yazkhiruni@um.edu.my

Nurmazilah Mahzan

Faculty of Business and Accounting, University of Malaya 50603 Kuala Lumpur, Malaysia

Tel: 60-3-7967-3962Ｅ-mail: nurmazilah@um.edu.my

\begin{abstract}
This paper investigates the disclosure quality of governance issues in annual reports of Malaysian PLCs. In recent years, the issue of corporate governance (CG) has received more attention than it would ordinarily have as a result of a series of corporate failures. Corporate collapses like Enron Corporation (US), Barings Empire (UK) and in Malaysia cases such as Perwaja and Pan Electric Inc. are all rooted in the lack of a proper governance system. As a result, the Finance Committee on Corporate Governance was established in 1998 to undertake a review of the legal and regulatory infrastructure, specifically to evaluate its effectiveness in promoting sound CG standards in Malaysia. Following this development, a few guidelines on CG have been released, particularly addressing the principles and best practices such as the Malaysian Code of Corporate Governance (the Code), the Capital Market Master Plan, and the Financial Sector Master Plan. The main purpose of these guidelines is to strengthen CG standards and practices in Malaysia by focusing on the role and responsibilities of various CG participants, mainly the management, board of directors, audit committee (AC), external and internal auditors. Secondary data is used in this study. A disclosure index is established following the Bursa Malaysia Governance Model, the Code's guidelines and Committee of Sponsoring Organizations of the Treadway Commission (COSO) guidelines. This study also aims to examine factors that possibly affect both the quality and quantity of disclosure. In general, it may be concluded that Malaysian companies have complied with the standards requirements. Only three factors under observation namely leverage, size and type of industry were found to have relationship with the quality of disclosure relates to governance issues.
\end{abstract}

Keywords: Disclosure quality, Corporate Governance, Management, Board of directors, External auditors, Internal auditors.

\section{Introduction}

Corporate governance (CG) has been a dominant policy issue in developed market economies for more than a decade. Hashim (2009) defines CG as "a combination of processes and structures conducted by the board of directors to authorize, direct and oversee management towards the achievement of the organization's objectives". He proposes the 
involvement of four different parties in the CG process. The first party would be the oversight group which particularly includes board and committees of the board in the organization; the second group suggested is the stewardship group which mainly comprises of executive management of an organization; thirdly, he has suggested the involvement of the performance group which basically consists of the operating and supporting management staffs within an organization; and finally, he has included the assurance group which encompasses of internal and external auditors. In the similar line of thought, Rezaee (2009) describes CG as "an ongoing process of managing, controlling, and assessing business affairs to create shareholder value and protect the interests of other stakeholders". According to him, there are seven essential functions of CG namely, oversight, managerial, compliance, internal audit, advisory, external audit, and monitoring.

In Malaysia, the revised Listing Requirements of 2001 delineates the requirements for financial reporting disclosures on matters relating to CG and continuing listing obligations. Non-compliance signifies a lack of integrity and poor CG practices. Further, for any non-compliance, companies are subject to fines and sanctions by Bursa Malaysia. Hence, effective Internal Audit Practices (IAP) in an organization will ensure conformance to the laws and regulations. According to Faudziah, Hasnah and Muhamad (2005), the Bursa Listing Requirements have established the industry taskforce to formulate the "Statement on Internal Control: Guidance for Directors of Public Listed Companies" in order to assist public listed companies (PLCs) to make disclosures in their annual reports on the state of internal control. They further mentioned that in May 2001, with reference to the requirements of the Code relating to the Internal Audit Function (IAF), the Securities Commission (SC) appointed the Institute of Internal Auditors Malaysia (IIAM) to establish a separate industry taskforce to formulate the Guidelines for the establishment of an IAF. Risk assessment, control environment, control activities, information and communication and monitoring are five significant characteristics in this guideline (Faudziah et al., 2005).

The paper is organized as follows; the first section provides a review of relevant literature on issues related to CG, followed by a discussion on the research methodology adopted in this study. The remaining sections report the findings and conclusion of the study.

\section{Literature Review and Research Questions}

\subsection{Corporate Governance and Quality of Financial Reporting}

The Sarbane-Oxley Act 2002 (SOX) was enacted to improve CG, quality of financial reports, and the credibility of the audit (internal and external) functions. Pursuant to this, the SOX Act described that interaction between the AC members, the external auditor, internal auditors, members of the board, and the management is crucial for effective governance and to achieve high quality financial reporting. Cooper, Leung and Wong (2006) conclude that the SOX Act has added the dimension of internal financial reporting assurance expected of internal auditors and AC. In recent years, there has been growing recognition of the importance of effective CG in ensuring sound financial reporting. Effective CG ensures credible accounting and high quality financial reporting, which provides the transparency of information that enables users, especially shareholders and investors to make informed decisions. Rezaee (2005) states that the members of the board are elected to act as shareholders' eyes and ears to ensure the creation of shareholders' value. Mallin (2003), on another note, states that CG has developed and grown significantly in the last decade. Numerous countries have issued CG codes including Malaysia (i.e. the Code) and the recommendations of these codes, that symbolize "good" CG, undoubtedly contribute towards increased transparency and disclosure. Yuan and Yuan (2007) suggest that CG has a greater impact on improving business efficiency than an internal control system. They emphasize that instead of strengthening the internal control system, improving CG is a more efficient way to prevent fraud and improve business efficacy (ICS). Nevertheless, there is an interaction between CG and ICS. Therefore, ICS will be improved along with the improvement of CG (Yuan and Yuan, 2007). Cohen, Krishnamoorthy and Wright (2004) suggest that $\mathrm{CG}$ can be one of the important functions in ensuring the quality of financial reporting. However, the notion of "quality financial reporting" remains a vague concept. A review of the extant literature reveals that despite providing a clear definition of what constitutes "quality financial reporting" researchers have focused on factors that can clearly inhibit the attainment of high quality financial reports (Cohen et al., 2004). According to them, factors such as earnings management, financial restatements and fraud have been used as evidence of failure in producing quality financial reporting. It was found that companies with financial reporting problems are less likely to have an AC that are dominated by outside directors, and few meet more than three times a year (Beasley 1996; McMullen and Raghunandan 1996; Beasley, Carcello, Hermanson and Lapides, 2000). Beasley et al. (2000), for example, found that the percentage of AC composed entirely of outside directors was lower for fraud related companies. They also found that AC for fraud companies met less often (generally once per year) compared to those of the fraud-free companies (generally two or three times per year).

\subsection{Required Disclosure about Internal Control Effectiveness}

Globalization of business, technological advancements, increasing business failures, and extensively publicized fraud in the US and abroad have encouraged organizations to stress their internal controls and IAF (Rezaee 1995). He notes that 
the COSO report re-emphasized the importance of internal controls in achieving an entity's objectives and gives momentum for entities to refocus attention on their systems of internal controls in an effort to make certain responsible $\mathrm{CG}$ and reliable financial reporting processes.

The Institute of Internal Auditors (IIA), in one of its newsletters, has highlighted that the SOX Act 2002 requires management of public companies both large and small to annually assess and report on the effectiveness of internal control over financial reporting (IIA, 2005). The Institute further suggested that businesses can rely on an industry standard, Internal Control - Integrated Framework, to evaluate and enhance their control systems. The COSO Framework, which was issued in 1992, was mentioned by the Institute for use as a blueprint to establish internal controls that promote efficacy, mitigate risks, and help ensure the reliability of financial statements as well as complying with laws and regulations. The framework is well known for its comprehensiveness, effectiveness, and principles of strong internal control.

With regards to the Malaysian environment, the Bursa Listing Requirements established an industry taskforce, which formulated the "Statement on Internal Control: Guidance for Directors of Public Listed Companies", to assist PLCs in making disclosures in their annual reports on the state of internal control, to comply with the Listing Requirements of the Bursa. Originally, it affirmed:

"...that a listed issuer must ensure that its board of directors includes in its annual report a statement about the state of internal control of the listed issuer as a group".

Bursa Listing Requirements (Paragraph 15.27(b))

In May 2001, with respect to the requirements of the Code on the subject of the IAF, the SC appointed the IIAM to set up a discrete industry taskforce to create these Guidelines to help the board of PLCs to effectively discharge their responsibilities in respect of establishing an IAF. There are five key characteristics in this guideline, namely, risk assessment, control environment, control activities, information and communication and monitoring (Faudziah et al., 2005). Further, the guidance requires directors to exercise judgment in reviewing how the company successfully implements the requirements of the Code relating to its internal control and subsequently reports the judgment to shareholders.

\subsection{Disclosure Quality and Related Theories on CG Issues}

There is no single model for CG but there are common elements that can be custom tailored to companies (Taher, 2003). According to him, the common elements generally pointed out are disclosure, transparency and accountability. Transparency in disclosing information enables governments and companies to respond to economic problems in a timely manner, and is necessary to prevent corporate scandals.

According to Mallin (2003) CG can be viewed from an agency perspective. The agency theory posits an inherent moral hazard problem in principal-agent (owner-manager) relations that gives rise to agency costs (Coles, McWilliams and Sen, 2001; Jensen and Meckling, 1976). Mallin (2003) argues that the report of the UK Committee on the Financial Aspects of CG, published in 1992 has significant influence on the development of CG not just in the UK, but in numerous other countries. Among others, the recommendations made include the establishment of key board committees comprising audit (composed of non-executive directors and responsible to the board); remuneration (responsible to the board for recommending remuneration of directors; nomination (a formal and transparent procedure for the appointment of new directors to the board); there should be at least three independent non-executive directors. The board should include a balance of executive and non-executive directors, so that no individual can dominate the board's decision making; and there should be separation between the roles of chair (responsible for running the board) and the chief executive officer responsible for running the business). These elements are also being emphasized in the Malaysian environment under the Bursa Listing Requirements.

In respect of other theories that relate to governance issues is the stewardship theory, which is another perspective that seeks to elucidate the behaviour of managers. Coles et al. (2001) have viewed this perspective as being complementary in respect to the agency and contracting explanations. Coles et al. (2001) have examined whether or not the presence of a steward as the manager would be able to mitigate agency problems and, thus, allow the corporation to reallocate resources that would have earlier been spent to provide additional monitoring and/or incentive mechanisms.

Naser and Nuseibeh (2003) note that the degree of compliance and the extent of corporate disclosure were used as a proxy of quality financial reporting; a high degree of compliance and more disclosure were viewed as better quality. They found that there is a high compliance with the mandatory requirements in all industries observed in their study except for the electricity sector. They further concluded that Saudi companies comply with the standards and disclose more than the minimum information required by law. However, in their opinion the level of voluntary disclosure is relatively low. Hasan and Karim (2005) investigated factors that influence the level of compliance by Bangladeshi companies with mandatory disclosure requirements. They state that the firm size, the qualifications of the accounting staff that prepare the financial statements and the reputation of the auditing firm have a significant positive impact on 
the quality of compliance to the mandatory disclosure requirements. This study aims to examine the information content of the selected statements related to the CG elements in the published annual reports of the selected PLCs on Bursa Malaysia, namely, the Statement of Internal Control, Statement of Corporate Governance and Audit Committee Report. This study aims to seek answers to the following research questions.

Research question 1: Do Malaysian PLCs comply with the requirements of mandatory disclosure?

Research question 2: Do Malaysian PLCs disclose additional information in accordance with the Best Practices/Voluntary standards?

Research question 3: Is there any association between disclosure quality and audit committee, board composition, size of company, profitability, auditor, and industry?

\subsection{Factors influencing the Disclosure Quality}

The review of the extant literature found that among others, audit committee, board composition, size of company, profitability, auditor, and industry have got an impact on the disclosure quality. Therefore, all these factors are examined in the context of the quality of disclosure relating to the selected governance issues.

Audit Committee and Board Composition:

According to Goodwin and Seow (2002) the Cadbury report published in 1992 recommended that the board of directors of a company should have a separate committee for overseeing the remuneration of executive directors and the auditing of the financial reporting. In other words, companies should have separate AC and remuneration committees. The same requirement is found under the Bursa listing requirements. Goodwin and Seow (2002), and Beasley et al. (2000) found that investors, auditors and directors believe that a strong and effective $\mathrm{AC}$ is able to assist external auditors in auditing the fraudulent accounting records and increase the level of quality disclosure. Ho and Wong (2001) found that companies, which have an AC, are more likely to have a higher extent of voluntary disclosure. It was found that a higher percentage of outside directors or independent directors within an AC can effectively monitor the management of a company, thus, reducing the opportunity for fraudulent reporting. Therefore, it is posited that the proportion of independent directors is positively related to the company's performances and its disclosure quality. The empirical evidence regarding this matter is mixed. Bujaki and McConomy (2002) stated that companies with a majority of independent directors are significantly more likely to disclose more information relating to CG issues than those that do not have a majority of independent directors. In another study, Eng and Mak (2003) found that there is negative relationship between the board composition and disclosure. Rationally, if there is a majority of unrelated directors, the monitoring process will be more effective since this group of directors does not have a direct personal interest in a particular company. Therefore, it is posited that:

H1: The number of independent $\mathrm{AC}$ members and the proportion of outside directors are positively related to the level of CG disclosure.

$\mathrm{H} 2$ : The existence of an AC is positively related to the level of voluntary disclosure made on CG information.

Size of company, Profitability and Leverage: The most common measures used by previous researchers to represent firm size includes capital stock turnover, market capitalization, total assets, market values of equity shares (McMullen, 1996; Forker, 1992; Wallace and Naser, 1995; Owusu-Ansah, 1998; Ho and Wong, 2001; Camferrman and Cooke, 2002; Eng and Mak, 2003 and Meek et al., 1995). In this study the total assets of a company has been used as a proxy for the firm size (Murphy, 1999; McMullen, 1996 and Ho and Wong, 2001). Various studies found a positive relationship between the firm size and the extent of disclosure in the corporate annual reports (Bujaki and McConomy 2002; Chau and Gray 2002; Laing and Weir 1999). McNally, Eng and Hasseldine (1982) argue that firm size is a dominant corporate characteristic in establishing the "leaders" in disclosure practices because of the great pressures from inside and outside of the company. According to Singhvi and Desai (1971), large companies normally use such information for managerial purposes, especially for monitoring internal reporting of the top management. The larger companies normally tend to disclose more information in order to convince and to promote their goodwill. The higher disclosure enables these large companies to maintain their reputation in the eyes of the public and to attract investors (Camfferman and Cooke 2002; Wallace and Naser 1995). Profitability is also another factor that is found to affect the extent of disclosure (Ahmad and Karim, 2005). The extant literature posits that a profitable company is likely to disclose more information to support the continuation of their position. Singhvi and Desai (1971) support this argument where they opined that higher earnings motivate management to provide greater disclosure of information in order to provide assurance to investors. In contrast, Bujaki and McConomy (2002) assert that firms facing a slowdown in revenue tend to increase their disclosure on issues relating to CG. However, previous researchers such as Wallace, Naser and Mora (1994) found that the association between the profitability and comprehensiveness of disclosure is not significant. In their study, profitability is measured using the net profit margin. Nevertheless, Owusu-Ansah (1998) found that there is a positive relationship between profitability and mandatory disclosure. This study aims to investigate whether there is any association between profitability and the disclosure quality related to the governance issues. The results suggest that 
highly leveraged firms have a wider obligation to disclose the information, especially the financial information in order to convince their long-term creditors that they have enough sources to fund the business. Empirical findings from the extant literature established that the relationship between leverage and the level of CG disclosure is mixed. Various studies provide support that leverage is positively correlated with disclosure (see for example, Bujaki and McConomy 2002), others found an insignificant effect (Chow and Wong-Borren, 1987). The agency theory predicts that the level of voluntary disclosure increases as the leverage of the firm grows. Jensen and Mekling (1976) argue that more highly leveraged companies incur higher monitoring costs whereby the board or management tends to increase the level of disclosure for monitoring purposes. Nevertheless, according to Eng and Mak (2003) increased leverage is expected to reduce disclosure because leverage helps to control the free cash flow problem and the agency costs of debt are controlled through restrictive debt covenants in debt agreement rather than increased disclosure information in annual reports. On the other hand, Ho and Wong (2001) found that the level of voluntary CG disclosure is not influenced by the agency cost of debt in Hong Kong listed companies. In this study leverage is represented by the total debt to equity ratio (Ho and Wong 2001). It indicates the ratio of debt on a companies' balance sheet to the amount of funds provided by the owner. Therefore, the third hypothesis for this study is:

H3: There is a positive association between the size of company, profitability, and leverage and the level of CG disclosure.

Auditor and Industry: According to Mallin (2003), CG can be viewed from an agency perspective. Coles et al. (2001) suggest that the presence of a steward as the manager may mitigate agency problems and enable the corporation to reallocate resources that would have earlier been spent on providing additional monitoring and/or incentive mechanisms. The size of the agency cost will also influence the choice of audit quality. The employment of a high quality auditor (big audit firm) may enhance good CG in one organization taking into consideration that the external auditor is one of the pillars of good CG. The review of the extant literature reveals that the type of industry is also one of the variables determining the level of disclosure in the corporate annual reports (Meek et al., 1995). The result of the empirical findings related to the type of industry and the level of disclosure is varied. For example, Meek et al. (1995) argue that the type of industry is the most important factor in explaining the level of the voluntary disclosures. Whereas, according to Eng and Mak (2003) there is no significant relationship between disclosure and the industry. According to Bujaki and McConomy (2002), the vast majority of firms in all industries provided CG disclosure but companies in the consumer products industry were particularly likely to provide more CG disclosure. Hence, the fourth hypothesis to be tested in this study is:

H4: There is a positive association between the auditor and the industry concerning the level of CG disclosure.

\section{Research methodology}

Annual reports represent one of the important sources of information for companies in Malaysia (Idris, 1997; Rahman, 2001; Yatim, 2004; Rusnah, 2006). Therefore, in this study annual reports of the selected PLCs were analysed to evaluate the quality of disclosure made on CG issues. For the purpose of this study, the disclosure indexes are based on the one developed in the two recent studies by Naser and Nuseibeh (2003) and Bujaki and McConomy (2002). Before the coding of the index is done for each company in the sample, a scoring sheet is prepared based on the mandatory and voluntary items stated in the Code, the Bursa Malaysia listing requirements, the COSO guidelines and the adjusted disclosures index developed by Bujaki and McConomy (2002). A scoring sheet was also used in previous research (Eng and Mak, 2003; Bujaki and McConomy, 2002; Chau and Gray, 2002). The scale of disclosure used in this study is either " 0 " or " 1 '. The contents of each annual report are reviewed and are compared to the discretionary items on the list and coded as " 1 " if disclosed or else "0" for the non-disclosure. Three disclosure indexes are constructed, which relate to the governance issues (particularly the information in the Statement of Internal Control, Statement of Corporate Governance and Audit Committee Report) taking into consideration the Bursa Malaysia Governance Model, the Code's guidelines and the COSO guidelines. To answer the first and second research questions, the disclosure index scored by each company is then divided with the maximum score (Naser and Nuseibah, 2003) to represent the disclosure quality. This can be presented mathematically as follows:

$$
\mathrm{I}_{x}=\left[\begin{array}{c}
n_{x} \\
\sum T_{t x}
\end{array}\right] / n_{x}
$$

where $\mathrm{I}_{x}$ is the index scored by company, $x, 0 \leq I_{x} \leq 1 ; T_{t x}$ is the information item disclosed by company $x ; n_{x}$ is the maximum number of items expected to be disclosed by a company.

For the third research question, a hypothesis is developed to examine the relationship between the disclosure quality (dependent variable) and the independent variables, namely, audit committee, size of company, profitability, leverage, auditor and industry as established in previous studies on disclosure quality (Eng and Mak 2003; Bujaki and McConomy 2002; Meek, Roberts and Gray 1995). The next section discusses the variables used in this study. 
Based on the above four hypotheses, the following model is formulated. The measurement of the dependent and experimental variables is based on the disclosure index developed by previous researchers (Bujaki and McConomy, 2002; Eng and Mak, 2003; Chau and Gray, 2002; and Meek et al., 1995).

DSCORE $=\beta 1$ AUDITCOM $+\beta 2$ OUTSIDERS $+\beta 3$ FSIZE + 4 PROFIT + $\beta 5$ LEV + $\beta 6$ AUDITOR + 37 IND + ej

Where:

DSCORE

$=$ Mandatory and Voluntary disclosure (Best Practices) scores

AUDITCOMM

$=$ Proportion of independent non-executive directors on the audit committee

OUTSIDERS

$=$ Percentage of outside directors on the board

FSIZE

$=$ Total assets

PROFIT

$=$ Net profit margin

LEV

AUDITOR

IND

$=$ Total debt to equity ratio

= Dummy variables, 1 if big audit firm, 0 otherwise

$=$ Dummy variables, 1 if the firm is in consumer product sector, 0 otherwise; 2 if the firm is in the industrial product sector, 0 otherwise; 3 if the firm is in the trading/services sector, 0 otherwise; 4 if the firm is in the infrastructure project sector, 0 otherwise; 5 if the firm is in the hotel sector, 0 otherwise; 6 if the firm is in the properties sector, 0 otherwise; 7 if the firm is in the plantation sector, 0 otherwise; 8 if the firm is in the construction sector, 0 otherwise; 9 if the firm is in the technology sector, 0 otherwise

$=$ Error term

A sample of 159 companies from the year 2006 was chosen randomly, comprising nine sectors (excluding the finance sector) listed on the main board of Bursa Malaysia. Secondary data was compiled from the annual reports of companies, which are available on the Bursa Malaysia website (www.bursamalaysia.com.my) and the Bursa library. The information for variables can normally be found on the Statement of Corporate Governance, Statement of Internal Control, Reports from Audit Committee and director's profiles whilst variables such as total assets, total revenues, total debts and profit after tax can be found in the Profit and Loss Statement and the Balance Sheet. Data was analysed using: (1) Descriptive statistics and (2) Multivariate test (Multiple Regression Analysis).

\section{Findings}

\subsection{Degree of compliance with standards requirements}

As mentioned earlier, the degree of compliance and the extent of corporate disclosure are used as a proxy for quality; looking at the individual items of disclosure that formed the index reported in Table 1, the conclusion is that all companies under observation disclosed information on most of the items in the index. For items forming the mandatory disclosure index, only a few companies failed to mention clearly about "the communication policy-management and shareholders" as well as "board should review the adequacy and form of director's compensation" (elements in the Code). A number of companies did not report on the human resources policy and procedures and reporting deficiencies (principles of internal control). However, in general, it may be concluded that the companies successfully complied with the standards requirements. The finding is consistent with the previous finding established by Naser and Nuseibeh (2003) who found a relatively high compliance with mandatory requirements among Saudi companies.

In addition, an examination of the descriptive statistics on individual disclosure items that formed the index in respect of the voluntary disclosures is depicted in Table 1. It shows that the Malaysian PLCs disclose most of the items except for the few companies that did not state clearly the part on the AC's role, mainly the item "To review the quarterly and year-end financial statements of the board, focusing particularly on the going concern assumption". It was found that the sample companies disclose detailed information on fifteen of the listed items, implying that the level of the voluntary disclosure is high. This is contrary to the findings obtained in the study done by Naser and Nuseibah (2003) due to the fact that the major proportion of companies in Saudi Arabia are owned either by families or the government, thereby giving little impetus to disclose the voluntary information. Further, major investors, and governmental agencies, either have access to company records or can demand whatever information they want. Therefore, public financial disclosure in Saudi Arabia is kept to a minimum. On the other hand, Malaysian PLCs face different challenges. In the context of the Malaysian economic and business environment, Malaysian companies are expending more effort to enhance the level of investors' confidence through solidarity of CG in the respective companies. Our findings also support the proposition that the outside directors have been effective in monitoring managers (the function of the AC) and protecting the interests of shareholders. It also shows that CG in Malaysia ensures that credible accounting and high quality financial reporting provides the transparency that enables users, especially shareholders and investors (most of them are public) to make informed decisions. Besides, it is consistent with the statement made by Rezaee (2005) in 
which the election of the board is to act as the eyes and ears of the shareholders to ensure the creation of shareholders' value.

The above findings can be attributed to the issuance of the revised Listing Requirements by Bursa Malaysia in 2001, which prescribed the requirements for financial reporting disclosures on CG matters and continuing listing obligations for Malaysian PLCs. Any non-compliance indicates a lack of integrity and poor CG practices. For any non-compliance, companies are subject to fines and sanctions by Bursa Malaysia. Consequently, an effective IAF in an organization will help to ensure compliance with laws and regulations.

\subsection{Results of hypotheses testing}

Table 2 reports the results of the linear regression for the sample companies. The dependent variable is the total disclosure score that was developed based on the Code, the Bursa Malaysia listing requirements, the COSO guidelines and various studies (Bujaki and McConomy, 2002; Eng and Mak, 2003; Chau and Gray, 2002; Meek et al., 1995). Table 2 presents the $R^{2}$ (coefficient of determination), F-ratio, beta coefficients and t-statistics for the model and summarizes the multiple regression results of Y (the Mandatory and the Voluntary disclosure scores) on the explanatory variables.

The results reflected in Table 2 show that there are no significant relationships between disclosure quality with the CG index score (mandatory disclosure) and AC's role index score (the voluntary disclosure) as well as with all the company characteristics (as indicated earlier including board composition; size; profitability; leverage; auditor and industry) except for the internal control index score (the mandatory disclosure). Overall, it may be concluded that Malaysian companies have complied with the standards requirements. It shows that Malaysian companies are aware of the sanctions for non-disclosure, whereby failure to disclose the matters set out in para 4.1 (the Code) in their annual reports, may result in companies facing action from the Bursa as stated in the Bursa listing requirements and section 11 of the Security Act 1983.

As reflected in Table 2, the value of $R^{2}$ is 0.257 ( $\mathrm{F}=3.304$ ) denoting that a slight percentage (approximately 26\%) of the variation in $\mathrm{Y}$ (principles of internal control that refers to the mandatory disclosure) can be explained by the variations in the set of independent variables (adjusted $R^{2}=0.180$ ). At the 0.05 level of significance, the hypothesis that all explanatory variable coefficients are simultaneously equal to zero is rejected. Only three independent variables entered the equation with a regression coefficient that was significant at the 0.05 level in the regression model. These variables include: size of company, leverage and one industry dummy variable (infrastructure industry).

The most significant independent variable is leverage followed by the size of company with $p$-values of $0.004(t=2.898)$ and $0.033(t=2.156)$, respectively. The results provide support for Hypothesis 3 except for profitability (which is not significant). The results indicate that more highly leveraged companies incur higher monitoring costs whereby the board or management tend to increase the level of disclosure for monitoring purposes. According to Bujaki and McConomy (2002), highly leveraged companies do provide more detailed discussion on the implementation of CG guidelines, consistent with an effort to convince investors and potential investors that they are effectively governed (LEV significant at the 0.07 level). The results obtained are also consistent with the argument made by Jensen and Meckling (1976).

In addition, large Malaysian PLCs normally use such information for managerial purposes, especially for monitoring internal reporting of top management. The results suggest that large companies tend to disclose more information in order to maintain their image and reputation in the eyes of the public and to attract investors. The finding is consistent with previous empirical studies, which found that large companies disclose more information to attract investors as the large companies need more financing than smaller companies (see Bujaki and McConomy 2002; Chau and Gray 2002; Camfferman and Cooke 2002; Ho and Wong 2001; Laing and Weir 1999; Wallace and Naser 1995; Singhvi and Desai 1971).

Another factor that influenced the disclosure quality on governance issues (internal control disclosure index score) is the type of industry i.e. infrastructure ( $p$-value $=0.035, t=2.128$ ), others are not significant. This is consistent with the findings established in Eng and Mak (2003) and Ho and Wong's (2001) studies but is inconsistent with the conclusion made by Bujaki and McConomy (2002). They concluded that the majority of larger companies in all industries provided CG disclosure, particularly companies in consumer products. Meanwhile, Ho and Wong (2001) found that the Banking and Finance industry was more likely to have a higher extent of voluntary disclosure as reputation is very important for companies in this industry.

\subsection{Discussion of findings}

Hypothesis 1, which states that the number of independent AC members and the proportion of outside directors are positively related to the level of CG disclosure was not supported. This finding is inconsistent with the findings established by McMullen (1996), which found that there is a strong correlation between the presence of AC and a high reliability of financial reporting. The previous empirical evidence relating to this issue is mixed. Bujaki and McConomy (2002) found that companies with a majority of outside directors are significantly more likely to disclose more CG 
issues than those that do not have a majority of outside directors. Eng and Mak (2003) found that there is a negative association between board composition and disclosure. They mentioned that the difference is due to the role played by independent directors. Outside directors may be elected by blockholders (who own a block of shares) to represent their interests and may be able to acquire information directly, rather than through public disclosure. Thus, a possible explanation of this result is that while AUDITCOMM and OUTSIDERS in Malaysia are likely to ensure that the company has complied with the mandatory as well as the voluntary disclosure requirements, they are still not actively pressing the company to disclose such information. Also there are questions about the independence of so-called 'independent' non-executive directors in Malaysia and their effectiveness as a monitoring device as many of them are appointed by the chief executive officer or the chairman of the board.

Hypothesis 2 states that companies that have an $\mathrm{AC}$ are more likely to have a higher extent of voluntary disclosure. Although the hypothesized direction was correct, it is not significant. Thus, implying that the existence of an AC does not effectively improve the transparency of information. Ho and Wong (2001) found that companies, which have an AC, are more likely to have a higher extent of voluntary disclosure. Forker (1992) only found a weak relationship between the existence of an $\mathrm{AC}$ and the quality (extent) of disclosure.

Hypothesis 3 states that there is a positive correlation between the size of company, profitability, and leverage, and the level of CG disclosure. Only size of company and leverage are significant and positively related to the level of CG disclosure. This is consistent with the findings of various studies such as Bujaki and Conomy (2002), Camfferman and Cooke (2002) and Wallace and Naser (1995). The finding implies that large Malaysian companies are likely to disclose more information with respect to CG information to maintain their image and reputation to gain public confidence as well as investors' interests. However, there is no evidence that profitability has an influence on the level of CG disclosure. This is consistent with the findings established in Wallace, et al. (1994) and Ho and Wong (2001). Bujaki and McConomy (2002) and Camfferman and Cooke (2002) found a negative relationship between profitability and the level of CG disclosure.

Hypothesis 4, which states that there is a positive association between the auditor and the industry with the level of CG disclosure, is not supported except for one industry dummy variable (infrastructure industry). In Malaysia, highly qualified auditors (big audit firm) may enhance CG in a company but to what extent they are actively involved in determining the level of disclosure with respect to governance issues in the corporate annual reports is still questionable. The result indicates that the Malaysian infrastructure industry is more likely to have a higher extent of CG disclosure compared to companies in the other industries. Eng and Mak (2003) found no evidence of a relationship between industry and the level of CG disclosure in Singapore. Bujaki and McConomy (2002) found that the consumer products industry is likely to provide more CG disclosure in Canada.

\section{Summary and conclusion}

In recent years, regulatory bodies have promulgated new CG requirements in order to enhance corporate transparency. In Malaysia, the Bursa listing requirements have raised the standards of CG of PLCs in order to enhance investor confidence and to further improve the integrity of the capital market. This study is aimed at examining various issues relating to the quality of information disclosed in the annual reports of the selected Malaysian PLCs. The descriptive statistics indicate that there is a relatively high compliance with the mandatory requirements as well as voluntary disclosure. The results of the analysis show a relatively high compliance with the mandatory requirements as well as voluntary disclosure in all companies under study, implying that they are aware of the sanctions that they might face for non-compliance.

The results also provide empirical evidence supporting certain hypotheses proposed in this study. It is found that only the size of company, leverage and the type of industry (i.e. the infrastructure industry) are positively related to the level of CG disclosure. The results suggest that companies that are big in size and highly leveraged as well as companies in the infrastructure industry tend to have a high level of CG disclosure.

Since Bursa Malaysia has promulgated various listing requirements to raise the standards of CG for PLCs in enhancing investor confidence it will be interesting to examine whether there is any association between the quality of disclosure on CG issues and the share prices among the Malaysian PLCs. If CG disclosures are able to enhance investor confidence then it is expected that the quality of disclosure on CG issues will positively associate with the share prices of a PLC. Future research may also consider conducting in-depth interviews to explore the possible issues, problems and challenges facing the relevant $\mathrm{CG}$ actors such as members of $\mathrm{AC}$, external auditors and internal auditors in maintaining good CG in a company.

\section{References}

Ahmad, J. U. \& Karim, A K M. W. (2005), Determinants of IAS disclosure compliance in emerging economies: Evidence from exchange listed companies in Bangladesh, Working Paper Series (21), Victoria University of Wellington, New Zealand. 
Beasley, M.S. (1996). An empirical analysis of the relation between the board of director composition and financial statement fraud. The Accounting Review, 71(4), 443-465.

Beasley, M.S., Joseph V. C., Dana R. H. \& Paul D. L. (2000). Fraudulent financial reporting: consideration of industry traits and corporate governance mechanisms." Accounting Horizons, 14(4), 441-454.

Bujaki. M. \& McConomy, B. (2002). Corporate governance: factors influencing voluntary disclosure by Publicly Traded Canadian Firms. Canadian Accounting Perspective, 1,105-39.

Cadbury Committee Report. (1992). Report of the Cadbury Committee on the financial aspects of corporate governance, Gee, London.

Camfferman, K. \& Cooke, T., E. (2002). An analysis of disclosure in the annual reports of U.K. and Dutch companies. Journal of International Accounting Research, 1(1), 3-30.

Chau, G.K. \& Gray, S.J. (2002). Ownership structure and corporate voluntary disclosure in Hong Kong and Singapore. International Journal of Accounting, 37(2), 247-265.

Chow, C.W. \& Wong-Boren, A. (1987). Voluntary financial disclosure by Mexican Corporations. The Accounting Review, 62(3), 533-541.

Cohen, J., Krishnamoorthy, Ganesh. \& Wright, A. (2004). The Corporate Governance Mosaic and Financial Reporting Quality." Journal of Accounting Literature 23: 87-152.

Coles, J. W., McWilliams, V. B. \& Sen, Nilanjan. (2001). An examination of the relationship of governance mechanismst performance. Journal of Management, 27 23-50.

Cooper, Barry J., Philomena, L. \& Grace, W. (2006). The Asia Pacific literature review on internal auditing. Managerial Auditing Journal, 21(6), 822-834.

Eng, L. L. \& Mak, Y.T. (2003). Corporate governance and voluntary disclosure. Journal of Accounting and Public Policy, 22, 325-345.

Faudziah, H. F., Hasnah, H. \& Muhamad, J. (2005). Internal auditing practices and internal control system. Managerial Auditing Journal, 20(8), 844-866.

Forker, J.J. (1992). Corporate governance and disclosure quality. Accounting and Business Research, 22 (86), 111-124.

Goodwin, J. \& Seow, J. L. (2002). The influence of corporate governance mechanisms on the quality of financial reporting and auditing: perceptions of auditors and directors in Singapore. Accounting and Finance, 42, 195-223.

Hasan, T. \& Karim, A K M. W. (2005). Regulatory change and the quality of compliance to mandatory disclosure requirements: evidence from Bangladesh, Working Paper Series (34), Victoria University of Wellington, New Zealand.

Hashim, M. (2009). Control and Governance - Organisational Performance, Paper Presented at the Half Day Seminar on Control and Governance organized under the Internal Audit Education Partnership (IAEP) Program with the US IIA Inc, 14 February, Kuala Lumpur.

Ho, S.S.M. \& Wong, K.S. (2001). A study of the relationship between corporate governance structures and the extent of voluntary disclosure. Journal of International Accounting, Auditing and Taxation, 10(2), 139-156.

Idris, F. (1997). Islamic Banks' Financial Reporting and its Usefulness to Investors. Unpublished Doctoral Dissertation. University of Cardiff, UK.

Institute of Internal Auditors [IIA]. (2005). Putting COSO’s Theory Into Practice.

Jensen, M. C. \& Meckling, W. H. (1976). Theory of the firm: managerial behavior, agency costs, and ownership structure. Journal of Financial Economics, 3, 305-360.

Laing, D. \& Weir, C.M. (1999). Governance structures, size and corporate performance in UK firms. Management Decision, 37(5), 457-464.

Mallin, C. (2003). The relationship between corporate governance, transparency and financial disclosure [Part I], United Nations Conference on Trade and Development, Geneva.

McMullen, D. A. (1996). Audit committee performance: an investigation of the consequences associated with audit committees. Auditing: A Journal of Theory and Practice, 15(1), 87-103.

McMullen, D. A. \& K. Raghunandan. (1996). Enhancing audit committee effectiveness. Journal of Accountancy 182(2), 79-81.

McNally, G.M., Eng, L. H. \& Hasseldine, C.R. (1982). Corporate financial reporting in New Zealand: an analysis of user preference, corporate characteristics and disclosure practice. Accounting and Business Research 13(49), 11-20.

Meek, G. K., Roberts, C.B. \& Gray, S.J. (1995). Factors influencing voluntary annual report disclosures by U.S., U.K 
and Continental European Multinational Corporations. Journal of International Business Studies, ${ }^{\text {rd }}$ Quarter, 555- 572.

Murphy, A. B. (1999). Firm characteristics of Swiss companies that utilize International Accounting Standards. The International Journal of Accounting, 34, (1), 121-131.

Naser, K. \& R. Nuseibah. (2003). Quality of financial reporting: evidence from the listed Saudi nonfinancial companies. The International Journal of Accounting, 38(1), 41-70.

Owusu-Ansah, S. (1998). The impact of corporate attributes on the extent of mandatory disclosure and reporting by listed companies in Zimbabwe. The International Journal of Accounting, 33(5), 605-631.

Rahman, A. A. (2001). The Use and Perceived Important of Annual Reports by Accountants in the Service Industry in Malaysia. Asian Review of Accounting, 9 (2), 117-128.

Rezaee, Z. (1995). What the COSO Report means for internal auditors. Managerial Auditing Journal, 10 (6), 5-9.

Rezaee, Z. (2005). Causes, consequences, and deterrence of financial statement fraud. Critical Perspective on Accounting, 16, 277-298.

Rezaee, Z. (2009). The Role of Internal Auditors in Corporate Governance, Paper Presented at the PhD Colloquium organized by Faculty of Business and Accountancy, 4 June, Kuala Lumpur.

Rusnah, M. (2006). Islamic Corporate Reports (ICRs) and Muslim Investors: The Case of the Islamic Banking Indusrty in Malaysia. Unpublished Doctoral Dissertation. University Malaya, Kuala Lumpur.

Singhvi, S. \& Desai, H.B. (1971). An empirical analysis of the quality of corporate financial disclosure. Accounting Review, 46 (1), $621-632$.

Taher, M. N. (2003). Corporate governance \& the Saudi capital market law. Arab News. [Online] Available: http://www.arabnews.com (November 3, 2003)

Wallace, R.S.O. \& Naser, K. (1995). Firm-Specific determinants of comprehensiveness of mandatory disclosure in the corporate annual reports of firms on the stock exchange of Hong Kong. Journal of Accounting and Public Policy, 14(4), 311-368.

Wallace, R.S.O., Naser, K. \& Mora, A. (1994). The relationship between the comprehensiveness of corporate annual reports and firm characteristics in Spain. Accounting and Business Research, 25(97), 41-53.

Yatim, M. M.N. (2004). Investors' Perception on the Usefulness of Corporate Annual Reports Issues by Islanmic Financial Institutions in Malaysia. Paper Presented at UNITEN Conference, Kuala Lumpur.

Yuan, J. \& Yuan, C. (2007). How to improve China's enterprise internal control system: based on the perspective of corporate governance. The Business Review, 7(2), 91-97.

Table 1. Descriptive statistics on items formed disclosure indexes

\begin{tabular}{|c|c|c|}
\hline \multirow[t]{2}{*}{ Item disclosed } & \multicolumn{2}{|c|}{2006} \\
\hline & Mean & $S D$ \\
\hline \multicolumn{3}{|l|}{ Items formed mandatory disclosure index } \\
\hline \multicolumn{3}{|l|}{ Corporate governance $(C G)$} \\
\hline Board has responsibility for strategic planning process & 0.96 & 0.19 \\
\hline Board has responsibility for identification of risks and risk management system & 0.99 & 0.11 \\
\hline Board has responsibility for succession planning & 1.00 & 0.00 \\
\hline Communication policy-management and shareholders & 0.56 & 0.50 \\
\hline Internal control and management information system & 1.00 & 0.00 \\
\hline $\begin{array}{l}\text { Reviewing the adequacy and the integrity of company's internal control system and management } \\
\text { system. }\end{array}$ & 1.00 & 0.00 \\
\hline Board should be constituted with a majority of unrelated directors & 0.96 & 0.19 \\
\hline $\begin{array}{l}\text { The circumstances of the company, whether it practices duality or separates the duties between } \\
\text { Chairman and CEO. }\end{array}$ & 0.92 & 0.26 \\
\hline $\begin{array}{l}\text { Firms should have a committee of directors for nominating new directors and assessing directors on } \\
\text { an ongoing basis }\end{array}$ & 1.00 & 0.00 \\
\hline Have a majority of whom are independent & 1.00 & 0.00 \\
\hline $\begin{array}{l}\text { Firms should implement a process for assessing the effectiveness of the board, its committee, and } \\
\text { individual directors }\end{array}$ & 0.90 & 0.30 \\
\hline An orientation and education programme should be provided to new board members & 1.00 & 0.00 \\
\hline Supply of information & 1.00 & 0.00 \\
\hline Board should consider its size and the potential for reduction & 1.00 & 0.00 \\
\hline $\begin{array}{l}\text { Remuneration procedure that indicates company has a formal and transparent procedure for } \\
\text { developing policy }\end{array}$ & 0.99 & 0.08 \\
\hline Remuneration that indicates the rationale and objective remuneration policy & 0.81 & 0.39 \\
\hline
\end{tabular}


Board should review the adequacy and form of director's compensation

0.50

Remuneration committee should be a majority of whom are unrelated

Remuneration committee should be remuneration information

Audit committee should be composed only of outside directors

Audit committee should have direct communication channels with internal and external auditors

Audit committee should have oversight responsibility for system of internal control

Audit Committee meeting that disclose in an informative way, details of the activities of audit

Dialogue between companies and investors that states AGM become a place to communicate

Internal Control (IC)

Integrity and ethical values

Importance of board of directors

Management philosophy and operating styles

Organizational structures

Commitment to financial reporting competencies

Authority and responsibility

Human Resources

Importance of financial reporting objectives

Identification and analysis of financial reporting risks

Assessment of fraud risk

Elements of a control activity such as performance reviews, information processing controls,

physical controls and segregation of duties.

Control activities linked to risk assessment

Selection and development of control activities

Information technology

Information needs

Information control

Management communication

Upstream communication

Board communication

Communication with outside parties

Ongoing monitoring

Reporting deficion.

Management roles (regular management supervisory activities in performing their duties)

Board and audit committee

Other personnel

Voluntary disclosure

Audit Committee's roles (ACR)

To consider the appointment of the external auditor, the audit fee and any questions of resignation or

To discuss with the external auditor before the audit commences, the nature and scope of the audit,

and ensure coordination where more than one audit firm is involved

To review the quarterly and year-end financial statements of the board, focusing particularly on any changes in accounting policies and practices

To review the quarterly and year-end financial statements of the board, focusing particularly on significant adjustment arising from the audit

To review the quarterly and year-end financial statements of the board, focusing particularly on the going concern assumption

To review the quarterly and year-end financial statements of the board, focusing particularly on

To discuss problems and reservations arising from the interim and final audits, and any matter the auditor may wish to discuss (in the absence of management where necessary)

To review the external auditor's management letter and management's response

Review the adequacy of the scope, functions and resources of the internal audit function, and that it has the necessary authority to carry out its work

Review the internal audit programme and results of the internal audit process, and where necessary, ensure that appropriate actions are taken on the recommendations of the internal audit function Review any appraisal or assessment of the performance of members of the internal audit function Approve any appointment or termination of senior staff members of the internal audit function 
Table 2. Empirical test on the relationship between disclosure quality on governance issues (DSCORE) and its attributes for all samples

Model Summary

\begin{tabular}{|c|c|c|c|c|c|c|}
\hline Model & \multicolumn{2}{|c|}{ R-Square } & \multicolumn{2}{|c|}{ Adjusted R-Square } & \multicolumn{2}{|c|}{$\mathrm{F}$} \\
\hline Corporate governance (CG) & \multicolumn{2}{|c|}{.106} & \multicolumn{2}{|c|}{.012} & \multicolumn{2}{|c|}{1.131} \\
\hline Internal control (IC) & \multicolumn{2}{|c|}{.257} & \multicolumn{2}{|c|}{.180} & \multicolumn{2}{|c|}{3.304} \\
\hline Audit committee's roles (ACR) & \multicolumn{2}{|c|}{.097} & \multicolumn{2}{|c|}{.003} & \multicolumn{2}{|c|}{1.029} \\
\hline \multicolumn{7}{|c|}{ Coefficient } \\
\hline \multicolumn{7}{|l|}{ Variables } \\
\hline & \multicolumn{2}{|c|}{$\mathrm{CG}$} & \multicolumn{2}{|c|}{ IC } & \multicolumn{2}{|c|}{ ACR } \\
\hline & $\begin{array}{c}\text { Coef } \\
(t)\end{array}$ & Sig. & $\begin{array}{c}\text { Coef } \\
(t)\end{array}$ & Sig. & $\begin{array}{c}\text { Coef } \\
(t)\end{array}$ & Sig. \\
\hline FSIZE & $\begin{array}{l}.004 \\
(.046)\end{array}$ & .963 & $\begin{array}{c}.163 \\
(2.156)\end{array}$ & $.033 *$ & $\begin{array}{c}.021 \\
(.252)\end{array}$ & .801 \\
\hline AUDITOR & $\begin{array}{l}.055 \\
(.667)\end{array}$ & .506 & $\begin{array}{c}.017 \\
(.227)\end{array}$ & .821 & $\begin{array}{c}.059 \\
(.705)\end{array}$ & .482 \\
\hline AUDITCOMM & $\begin{array}{c}-.038 \\
(-.457)\end{array}$ & .648 & $\begin{array}{c}.129 \\
(1.717)\end{array}$ & .088 & $\begin{array}{c}.105 \\
(1.269)\end{array}$ & .207 \\
\hline OUTSIDERS & $\begin{array}{c}-.051 \\
(-.600)\end{array}$ & .550 & $\begin{array}{c}-.063 \\
(-.809)\end{array}$ & .420 & $\begin{array}{c}.046 \\
(.529)\end{array}$ & .598 \\
\hline LEV & $\begin{array}{c}-.033 \\
(-.326)\end{array}$ & .745 & $\begin{array}{c}.265 \\
(2.898)\end{array}$ & $.004 *$ & $\begin{array}{c}.102 \\
(1.008)\end{array}$ & .351 \\
\hline PROFIT & $\begin{array}{l}.041 \\
(.452)\end{array}$ & .652 & $\begin{array}{c}.111 \\
(1.341)\end{array}$ & 182 & $\begin{array}{c}.095 \\
(1.040)\end{array}$ & .300 \\
\hline IND & & & & & & \\
\hline -consumer product & $\begin{array}{c}.056 \\
(.172)\end{array}$ & .864 & $\begin{array}{c}.090 \\
(.305)\end{array}$ & .761 & $\begin{array}{c}-.039 \\
(-.121)\end{array}$ & .904 \\
\hline - industrial product & $\begin{array}{c}-.041 \\
(-.130)\end{array}$ & .896 & $\begin{array}{l}.196 \\
(.676)\end{array}$ & .500 & $\begin{array}{l}.131 \\
(.410)\end{array}$ & .682 \\
\hline - trading/services & $\begin{array}{c}.080 \\
(.303)\end{array}$ & .763 & $\begin{array}{c}.386 \\
(1.604)\end{array}$ & .111 & $\begin{array}{c}.062 \\
(.235)\end{array}$ & .814 \\
\hline - infrastructure & $\begin{array}{c}.153 \\
(1.352)\end{array}$ & .178 & $\begin{array}{c}.220 \\
(2.128)\end{array}$ & $.035^{*}$ & $\begin{array}{c}-.111 \\
(-.973)\end{array}$ & .332 \\
\hline - hotel & $\begin{array}{c}-.171 \\
(-1.250)\end{array}$ & .213 & $\begin{array}{c}.120 \\
(.958)\end{array}$ & .339 & $\begin{array}{c}.083 \\
(.603)\end{array}$ & .548 \\
\hline - properties & $\begin{array}{c}-.138 \\
(-.184)\end{array}$ & .854 & $\begin{array}{l}.081 \\
(.430)\end{array}$ & .668 & $\begin{array}{c}.081 \\
(.389)\end{array}$ & .698 \\
\hline - plantation & $\begin{array}{l}-.025 \\
(-.138)\end{array}$ & .890 & $\begin{array}{l}.142 \\
(.857)\end{array}$ & .393 & $\begin{array}{c}.051 \\
(.278)\end{array}$ & .781 \\
\hline - construction & $\begin{array}{c}.151 \\
(.598)\end{array}$ & .551 & $\begin{array}{c}.031 \\
(.564)\end{array}$ & .574 & $\begin{array}{c}.123 \\
(.486)\end{array}$ & .628 \\
\hline
\end{tabular}

Note: * significant at 5\% significance level 